\title{
Pregnancy Pilates and Benefits of Pregnancy Pilates during Childbirth
}

\author{
Dilek Sarpkaya Güider \\ Faculty of Nursing, Near East University, Nicosia, Cyprus
}

Submission: April 14, 2018; Published: May 21, 2018

*Corresponding author: Dilek Sarpkaya Güder, Faculty of Nursing, Near East University, Near East Boulevard, ZIP: 99138, Nicosia, Cyprus, Tel: 053388380 66; Email: dilek.sarpkaya@neu.edu.tr

\begin{abstract}
The aim of this study is to explain the pregnancy Pilates and benefits of pregnancy Pilates during childbirth. Pilates performed during pregnancy is a safe and effective exercise system which prepares and strengthens expectant mothers for delivery from the first to the last month of pregnancy. Pilates can be performed at least two or three times a week from the beginning of pregnancy. It is recommended that Pilates should be done for 15 to 20 minutes during the first months of pregnancy, and for 45 to 60 minutes during the following months. Pilates movements for abdomen, upper body, arms, back, feet and legs and pelvic floor, which are performed on the mat. The number of studies showing the effects of Pilates performed during pregnancy on the birth process is limited. Pilates can reduce the fear of childbirth. Women who did Pilates during pregnancy can cope with contractions using their diaphragmatic breath, give birth comfortably. Preparing for childbirth with Pilates can help in the dilation of the cervix during contractions, thus allowing the baby to pass through, the muscles to relax, and the diaphragm to provide the necessary support. It can be positive effects on delivery outcomes as. This study recommends that further studies should examine the effect of Pilates on fear of delivery, delivery type, the duration of the first and second stages of birth, the number of interventions during delivery, pain during labor and coping with this pain, problems during delivery, satisfaction with the birth experience, as well as delivery results, including the weight of the newborn and the Apgar score.
\end{abstract}

Keywords: Birth; Delivery; Exercise; Pilates; Pregnancy

\section{Introduction}

Pilates is an exercise approach which was developed by German Joseph Hubertus Pilates at the beginning of the twentieth century. It was called «contrology». Pilates has six basic principles: concentration, control, centering, flow, precision and breathing [1,2]. Pilates, a mind-body exercise program, may be an appropriate recommendation for expectant mothers because it offers tangible physical benefits in addition to emotional and mental benefits [3]. Pilates performed during pregnancy is a safe and effective exercise system which prepares and strengthens expectant mothers for delivery from the first to the last month of pregnancy [4,5]. Pilates can be performed at least two or three times a week from the beginning of pregnancy. It is recommended that Pilates exercises should be done for 15 to 20 minutes during the first months of pregnancy, and for 45 to 60 minutes during the following months. Moreover, each movement includes 5 to 10 repetitions depending on the type of the Pilates movement, and the exercises can be increased gradually ( $\sim 20$ repetitions). In accordance with the principles of Pilates, doing each movement precisely has more importance than doing a higher number of repetitions. The contrology method of Pilates has 34 matwork exercises [6]. Along with 18 basic movements that pregnant women can perform, the number of exercises can be increased by using different versions of these movements, performed with band, hoop and Pilates ball $[1,5,6]$. The Pilates balls used for these exercises can help improve balance and make a difference in the movements [2]. Moreover, movements can be much easier for pregnant women when they are performed with the support of materials such as the band and hoop. Pilates programs for pregnant women include basic Pilates movements for abdomen, upper body, arms, back, feet and legs and pelvic floor, which are performed on the mat [4]. It is ideal for Pilates classes to include five or six people. Pilates classes can be carried out as one-on-one personalized sessions, or with a maximum of eight people, depending on the size of the location. During each Pilates session, at least three movements for each region can be practiced. As an example, a pilates session includes warm-up exercises (such as chest stretch, swinging, one arm circles, toy soldier, side rotation), band, hoop and ball-supported basic Pilates movements such as the double leg stretch, the one leg circles, the hundred, the spine twist, the saw, the side kick, shoulder bridge, the spine stretch, swimming, leg pull front, the side kick kneeling, the leg-pull and the pelvic floor exercises performed on the ball.

\section{Discussion}

Past studies have found that exercising reduces the fear of childbirth and has positive effects on delivery outcomes [7-15]. 
Exercise-based prenatal education can result in positive birth outcomes as measured by Apgar score and weight [16]. Studies showed that exercises performed during the early period of pregnancy have an effect mostly on the placental development, and moderately-intense exercises started at the $20^{\text {th }}$ week of pregnancy have an effect on the fetal growth [7-17].

The number of studies showing the effects of Pilates performed during pregnancy on the birth process is limited [18]. A study conducted by Aktan [7] compared the birth outcomes of pregnant women who received both clinical Pilates training and education in preparing for childbirth, with those who received only education in preparing for childbirth and with those of the control group. The first-minute Apgar scores of newborns of women who received clinical Pilates exercise and training in preparing for childbirth were found to be higher, compared to those of women who received only childbirth preparation training, and who were included in the control group. Among the women who had a vaginal birth, those who received clinical Pilates training and childbirth preparation education, and those who received only childbirth preparation training had lower pain intensity during delivery, compared to the women in the control group [7]. The same study found no significant difference between the pregnant women who received clinical Pilates and labor and delivery training, and those who received only training in preparing for labor and delivery, and those in the control group, in terms of type of birth, duration of labor, and the weight of the newborns [7]. According to a study by Sarpkaya Güder et al. [19] pregnancy pilates-assisted childbirth preparation training has been shown to reduce fear of childbirth and pain, increase the number of vaginal births, and improve the Apgar score and body weight of the newborn $[19,20]$ There was no significant difference observed between the two groups in reference to interventions during delivery, total delivery time, and the development of problems in women during delivery. The same study found according to the control group, women in the experimental group reported that they had more support at birth, more coping techniques for birth pain, fewer problems during the birth process and more satisfaction with the birth experience [20].

Pilates can reduce the fear of childbirth and help expectant mothers to be affected less by emotional fluctuations. Studies showed that women who did Pilates during pregnancy can cope with contractions using their diaphragmatic breath, give birth comfortably, and had a lower number of tears that may occur during childbirth $[4,6]$. In pregnancy Pilates, the imaging technique that is used in relation to the movement flow principle, as well as the breathing techniques, are beneficial in preparing expectant mothers for childbirth. The imaging technique that is used when doing Pilates can help prepare for the use of imaging techniques during delivery. Preparing for childbirth with Pilates can help in the dilation of the cervix during contractions, thus allowing the baby to pass through, the muscles to relax, and the diaphragm to provide the necessary support. Using diaphragmatic breathing and a variety of exhaling techniques to strengthen the diaphragm can help the uterine muscles to work effectively during delivery and can be good for pushing as well [4]. It is reported that doing Pilates in the post-natal period helps the uterus return to normal more easily and quickly, and the loose and elongated abdominal muscles to strengthen much faster $[4-6,9]$.

\section{Conclusion}

This study recommends that further studies be conducted on doing Pregnancy Pilates during childbirth. The studies should examine the effect of Pilates on fear of delivery, delivery type, the duration of the first and second stages of birth, the number of interventions during delivery, pain during labor and coping with this pain, problems during the birth process and satisfaction with the birth experience, as well as delivery results, including the weight of the newborn and the Apgar score.

\section{Conflict of Interest}

The author declare no conflicts of economic interest or any conflict of interest in connection with this article.

\section{References}

1. Isacowitz R, Clippinger K (2010) Pilates anatomy. Human Kinetics, New Zealand.

2. Knight L (2004) Lucy Knight's pilates gymball workout. IMC Vision.

3. Dillard DM (2013) Perinatal pilates. International Journal of Childbirth Education 28(1): 20-25

4. International Pilates Federation (IPF) (2011) Hamile pilatesi eğitim modülü, Izmir.

5. King M, Green Y (2002) Pilates workbook for pregnancy. Octopus Publishing Group, Canada.

6. Herdman A, Godfrey WJ (2005) A gaia busy person's guide pilates. Simple routines for home, work \& travel. Pilates for pregnancy, Gaia Books, China.

7. Aktan B (2015) Klinik pilates egzersizleri ve doğuma hazırlık eğitiminin sadece doğum eğitimine göre doğum sonuçları üzerine etkisi. Hacettepe Üniversitesi Sağlık Bilimleri Enstitüsü. Fizik Tedavi ve Rehabilitasyon Programı, Yüksek Lisans Tezi, Ankara.

8. Bergström M, Kieler H, Waldenström U (2009) Effects of natural childbirth preparation versus standard antenatal education on epidural rates, experience of childbirth and parental stress in mothers and fathers: a randomised controlled multicentre trial. BJOG 116(9): 1167-1176.

9. Chuntharapat S, Petpichetchian W, Hatthakit U (2008) Yoga during pregnancy: effects on maternal comfort, labor pain and birth outcomes. Complement Ther Clin Pract 14(2): 105-115.

10. Jeyrani MN, Zeidi BM, Malekzadegan A, Hossaini F (2009) The effect of child birth preparation classes on fear of childbirth and severity of 
labor pain in pregnant women reoffered to Akbara bady hospital of Tehran, 2008 (Oral presentations). International Journal of Gynecology \& Obstetrics, pp. 93-396.

11. Forouhari S, Yazdanpanahi Z, Parsanezhad ME, Raigan Shirazi M (2009) The effects of regular exercise on pregnancy outcome. Iranian Red Crescent Medical 11(1): 57-60.

12. Guszkowska M (2014) The effect of exercise and childbirth classes on fear of child birth and locus of labor pain control. Anxiety, Stress \& Coping 27(2): 176-189.

13. Ghodsi Z, Asltoghiri M (2012) Does exercise training during pregnancy affect gestational age and gestational weight gain? Procedia -Social and Behavioral Sciences 31: 418-422.

14. Laursen, M, Johansen C, Hedegaard M (2009) Fear of childbirth and risk for birth complications in nulliparous women in the Danish National Birth Cohort. BJOG 116(10): 1350-1355.

15. Rad LS, Jahanshiri A (2013) Effect of a period of exercise during pregnancy on certain delivery parameters. European Journal of Experimental Biology 3(2): 78-85.
16. Price BB, Amini SS, Kappeler K (2012) Exercise in pregnancy: effect on fitness and obstetric outcomes-a randomized trial. Med Sci Sports Exerc 44(12): 2263-2269.

17. Hopkins SA, Cutfield WS (2011) Exercise in pregnancy: weighing up the long-term impact on the next generation. Exerc Sport Sci Rev 39(3): 120-127

18. Bernardo LM (2007) The effectiveness of Pilates training in healthy adults: An appraisal of the research literatüre. Journal of Bodywork and Movement Therapies 11(2): 106-110.

19. Sarpkaya Güder D, Yalvaç M, Vural G (2018) The effect of pregnancy Pilates-assisted childbirth preparation training on childbirth fear and neonatal outcomes: a quasi-experimental/quantitative research. Quality \& Quantity, pp. 1-13.

20. Sarpkaya Güder D (2018) Primipar kadınlara verilen doğuma hazırlık eğitiminin doğum korkusu ve sonuçlarına etkisi. Yakın Doğu Üniversitesi Sağlık Bilimleri Enstitüsü, Hemșirelik Programı, Doktora Tezi, Lefkoșa.

\section{Your next submission with Juniper Publishers} will reach you the below assets

- Quality Editorial service

- Swift Peer Review

- Reprints availability

- E-prints Service

- Manuscript Podcast for convenient understanding

- Global attainment for your research

- Manuscript accessibility in different formats

(Pdf, E-pub, Full Text, Audio)

- Unceasing customer service

Track the below URL for one-step submission https://juniperpublishers.com/online-submission.php 